\title{
Kausalitas Mental Accounting dan Pengambilan Keputusan Investasi Mesin Produksi: Suatu Studi Eksperimen
}

\author{
Fadlil Abdani1*, Fajar Nurdin² \\ 1,2 UIN Maulana Malik Ibrahim Malang \\ 'fadlilabdani@uin-malang.ac.id, 2nurdin.fajar@uin-malang.ac.id \\ ${ }^{*}$ Penulis Korespondensi
}

\begin{abstract}
This research is included in the true experiment which aims to test the main effect and the interaction effect of mental accounting and self efficacy on investment decisions on production machinery. The method used is the true experiment, with the design of $2 \times 2$ between subjects that uses two levels of mental accounting (existing or absent) and two levels of self efficacy (high or low). Statistical tests are used with ANOVA, for the first and second hypotheses using One Way Analysis of Variance and for the third hypothesis using Two Way Analysis of Variance. The results of the study found that mental accounting proved to influence the investment decision making of production machinery. Self efficacy is also proven to have an effect on investment decisions in production machinery. While the interaction effect between mental accounting and self efficacy does not affect the investment decision making of a production machine.
\end{abstract}

Keywords: mental accounting, self efficacy, behavioral accounting, decision making

\begin{abstract}
Abstrak
Penelitian ini termasuk dalam true experiment yang bertujuan untuk menguji main effect maupun interaction effect variabel mental accounting dan self efficacy terhadap pengambilan keputusan investasi mesin produksi. Metode yang digunakan adalah true experiment, dengan desain $2 \times 2$ between subject yang menggunakan dua level kondisi mental accounting (ada atau tidak ada) dan dua level kondisi self efficacy (tinggi atau rendah). Uji statistik yang digunakan dengan Analysis of Variance (ANOVA), untuk hipotesis pertama dan kedua menggunakan One Way Analysis of Variance dan untuk hipotesis ketiga menggunakan Two Way Analysis of Variance. Hasil penelitian menemukan bahwa mental accounting terbukti berpengaruh terhadap pengambilan keputusan investasi mesin produksi. Self efficacy juga terbukti berpengaruh terhadap pengambilan keputusan investasi mesin produksi. Sementara efek interaksi antara mental accounting dan self efficacy tidak berpengaruh terhadap pengambilan keputusan investasi mesin produksi.
\end{abstract}

Kata Kunci: mental accounting, self efficacy, behavioral accounting, pengambilan keputusan 


\section{PENDAHULUAN}

Setiap perusahaan pasti memiliki tujuan untuk mengelola organisasi agar dapat menciptakan keunggulan kompetitif dibandingkan kompetitornya. Berada dalam suatu industri yang kompetitif mengharuskan suatu perusahaan memiliki daya saing tersendiri, sehingga perusahaan dapat bertahan ataupun dapat lebih unggul. Salah satu cara mengahdapi persaingan adalah dengan menganalisis bagaiamana kekuatan karakteristik suatu industri, Porter (1989) menggambarkan "Five Force Model" sebagai alat analisis suatu industri, meliputi; ancaman pendatang baru, kekuatan tawar menawar pemasok, ancaman produk pengganti, kekuatan tawar menawar pembeli, dan persaingan di antara anggota industri. Tuntutan perusahaan yang ada dalam industri tersebut untuk bersaing menimbulkan pelbagai alternatif pengambilan keputusan strategi bisnis sesuai dengan tujuan perusahaan, baik itu pengambilan keputusan pada internal perusahaan berupa; inovasi hasil produksi atau investasi alat-alat produksi, maupun pengambilan keputusan eksternal berupa; investasi di pasar modal guna memperoleh dana untuk operasional perusahaan.

Salah satu alternatif dalam pengambilan keputusan, berupa keputusan investasi internal maupun eksternal menjadi hal penting untuk masa depan perusahaan. Pengambilan keputusan investasi yang dilakukan oleh sebuah perusahaan dapat dipandang dari 2 (dua) sisi, yakni pengambilan keputusan investasi (eksternal) yang merupakan pengambilan keputusan investasi melalui transaksi jual beli surat berharga di bursa efek yang bertujuan untuk mendistribusikan atau menghimpun modal dari pihak luar. Sedangkan pengambilan keputusan investasi dari sudut pandang (internal) perusahaan merupakan pengambilan keputusan investasi untuk membenahi atau memaksimalkan nilai perusahaan dengan cara melakukan pengambilan keputusan investasi sistem produksi yang terintegrasi dan juga investasi mesin produksi.

Pengambilan keputusan investasi bukanlah sebuah keputusan yang mudah karena menyangkut masa depan perusahaan, mengandung ketidakpastian dan berisiko. Berdasarkan kondisi ketidakpastian dan berisiko tersebut, para manajer dituntut untuk mampu mengambil alternatif keputusan terbaik yang disebut dengan keputusan yang rasional. Hal ini disadari telah menciptakan sebuah permasalahan tersendiri antara principal dengan manajer.

Pengambilan keputusan investasi disebabkan dua hal yaitu faktor ekonomi klasik dan faktor prilaku keuangan (Nagy \& Obenberger 1994; Ritter 2003). Faktor ekonomi yang dimaksud adalah informasi akuntansi dan kompensasi. Informasi akuntansi dapat digunakan manajer untuk memutuskan pengambilan keputusan investasi mana yang layak atau tidak layak dilakukan. Sementara lebih jauh, faktor prilaku keuangan terdiri dari gender, pola perilaku terhadap risiko (risk attituted), mental accounting (akuntansi mental), terlalu percaya diri, dan sikap ketakutan atau tamak yang semuanya dimiliki oleh manajer (Nagy and Obenberger, 1994). Selain itu, terdapat faktor psikologis yang memengaruhi keputusan seorang investor (Bakar \& Yi, 2016).

Menurut Nahartyo and Utami (2016) menegaskan bahwa seseorang seringkali 
berperilaku tidak rasional dan membuat perkiraan-perkiraan yang keliru ketika dia mengambil sebuah keputusan. Prilaku tidak rasional ini seringkali disebabkan oleh beberapa hal yang melekat dalam diri individu, oleh karena itu pada penelitian ini focus untuk mengambil dua hal; mental accounting dan self efficacy dianggap sebagai mewakili behavioral finance dalam pengambilan keputusan investasi mesin produksi. Mental accounting adalah suatu prilaku kognitif manusia yang digunakan untuk membuat kategori serta mengevaluasi situasi ketika terdapat dua atau lebih kemungkinan hasil, khususnya bagaimana mengkombinasikan kemungkinan-kemungkinan dari hasil tersebut (Thaler, 1985). Sedangkan self efficacy dikenalkan pertama kali oleh Bandura (1978) adalah judgement sesorang terhadap kemampuan dirinya sendiri dalam mencapai tingkatan kerja yang diinginkan atau ditentukan, selanjutnya akan mempengaruhi tindakan.

Mental accounting merupakan bagaimana seseorang memperlakukan keuangannya dalam pos-pos tertentu. Mental accounting berfokus pada bagaimana seseorang seharusnya menyikapi dan mengevaluasi kemungkinan-kemungkinan yang terjadi. Fenomena mental accounting yang dikenalkan Thaler (1985) ide dasarnya berpijak pada teori prospek yang dikembangkan oleh Kahneman \& Tversky (1979). Lebih dari itu, mental accounting dapat didefinisikan sebagai prilaku sesorang dalam menggolongkan atau membuat kategori pemasukan dan pengeluaran keuangannya.

Nagy \& Obenberger (1994) menyatakan bahwa faktor-faktor yang mempengaruhi pengambilan keputusan investasi menjadi dua hal, yaitu faktor ekonomi dan faktor behavior finance. Salah satu representasi dari behavior finance adalah mental accounting. Mental accounting merupakan suatu prilaku kognitif manusia yang digunakan untuk membuat kategori serta mengevaluasi situasi ketika terdapat dua atau lebih kemungkinan hasil, khususnya bagaimana mengkombinasikan kemungkinan-kemungkinan dari hasil tersebut (Thaler, 1985).

Psikologi kognitif berupa mental accounting ini memang dapat dikaitkan dengan berbagai hal dalam pengambilan keputusan, kegiatan rumah tangga, dan investasi. Pada penelitian yang dilakukan oleh Thaler (1985) tidak ditemukan mental accounting, dan kasus Kahneman \& Tversky (1984) juga tidak ditemukan mental accounting.

Berdasarkan beberapa uraian penelitian tersebut, maka peneliti menyusun hipotesis berupa, $\mathrm{H}_{1}$ : Manajer yang berada dalam kondisi mental accounting cenderung akan melakukan investasi mesin produksi.

Faktor internal berupa overconfidence, emotion, mental accounting, experience merupakan bagian dari psikologi kognitif yang banyak digunakan dalam penelitian behavioral accounting. Bertujuan untuk menguji faktor internal terhadap risk perception dan expected return perception yang menemukan hasil bahwa pengaruh faktor internal signifikan yaitu overconfidence, emotion, mental accounting, dan experience terhadap risk perception (Rengku, 2012). Self efficacy juga merupakan representasi dari behavior finance. Self efficacy dikenalkan pertama kali oleh Bandura (1978) yang menyatakan bahwa self efficacy adalah judgement sesorang terhadap kemampuan dirinya sendiri dalam mencapai tingkatan kerja yang diinginkan atau ditentukan, selanjutnya akan mempengaruhi tindakan. 
Pada kondisi self efficacy yang tinggi, subyek cenderung akan melakukan eskalasi komitmen (Whyte dkk, 1997; Whyte \& Saks, 2007). Sedangkan sebaliknya, pada kondisi self efficacy yang rendah subyek cenderung tidak melakukan eskalasi komitmen. Hal yang sama juga ditemukan oleh Montford and Goldsmith (2016), bahwa keyakinan diri yang tinggi berpengaruh terhadap pemilihan investasi yang berisiko. Lebih lanjut, ada dua variabel yang dibahas meliputi; gender dan sel efficacy, kedua variabel tersebut, dibuktikan terkudung hipotesisnya. Di mana perempuan lebih cenderung berhati-hati dalam memilih investasi berisiko, berbanding terbalik dengan laki-laki yang lebih berani dalam memilih investasi yang berisiko.

Biyanto (2001) menemukan bahwa pembingkaian informasi anggaran berpengaruh terhadap pilihan keputusan investasi berisiko. Begitu juga dengan pengalaman, dapat dibuktikan bahwa pengalaman berpengaruh signifikan terhadap pengambilan keputusan investasi. Sedangkan tanggung jawab terbukti tidak berpengaruh terhadap pilihan keputusan investasi berisiko. Sementara hal yang berbeda ditemukan oleh Montford and Goldsmith (2016), bahwa keyakinan diri yang tinggi berpengaruh terhadap pemilihan investasi yang berisiko.

Berdasarkan beberapa uraian penelitian di atas, maka peneliti menyusun hipotesis berupa, $\mathrm{H}_{2}$ : Manajer yang berada dalam kondisi self efficacy yang tinggi cenderung akan melakukan investasi mesin produksi.

Terdapat dua hal yang merepresentasi dari behavior finance adalah mental accounting dan self efficacy. Mental accounting merupakan suatu prilaku kognitif manusia yang digunakan untuk membuat kategori serta mengevaluasi situasi ketika terdapat dua atau lebih kemungkinan hasil, khususnya bagaimana mengkombinasikan kemungkinankemungkinan dari hasil tersebut (Thaler 1985). Sedangkan self efficacy menurut Bandura (1978) adalah judgement sesorang terhadap kemampuan dirinya sendiri dalam mencapai tingkatan kerja yang diinginkan, selanjutnya akan mempengaruhi tindakan yang ia lakukan.

Rengku (2012) melakukan penelitian menggunakan faktor internal berupa overconfidence, emotion, mental accounting, Experience merupakan bagian dari psikologi kognitif yang banyak digunakan dalam penelitian behavioral accounting. Bertujuan untuk menguji faktor internal terhadap risk perception dan expected return perception yang menemukan hasil bahwa pengaruh faktor internal signifikan yaitu overconfidence, emotion, mental accounting, dan experience terhadap risk perception.

Berdasarkan beberapa uraian penelitian terdahulu di atas, maka peneliti menyusun hipotesis interaksi antara kedua variabel mental accounting dengan self efficacy sebagai berikut, $\mathrm{H}_{3}$ : Manajer yang berada dalam kondisi adanya mental accounting dan self efficacy yang tinggi cenderung akan melakukan investasi mesin produksi

\section{METODE}

Penelitian ini menggunakan metode eksperimen. Metode eksperimen yang digunakan pada penelitian ini dengan eksperimen tulen atau eksperimen randomisasi (Nahartyo 
\& Utami, 2016), dimana kondisi variabel dibawah kendali peneliti, variabel independen diberikan manipulasi yang selanjutnya akan diamati efek terhadap variabel independen.

Penelitian ini menguji pengaruh mental accounting dan self efficacy terhadap pengambilan keputusan investasi mesin produksi dengan desain $2 \times 2$ between-subject, berarti bahwa eksperimen ini menggunakan dua level kondisi mental accounting (ada atau tidak ada), dan dua level kondisi self efficacy (tinggi atau rendah). Desain penelitian dapat ditunjukkan oleh Tabel 1.

Tabel 1. Desain Penelitian

\begin{tabular}{ccc}
\hline \multirow{2}{*}{ Self Efficacy } & \multicolumn{2}{c}{ Mental Accounting } \\
& Ada & Tidak ada \\
\hline Tinggi & Grup 1 & Grup 2 \\
Rendah & Grup 3 & Grup 4 \\
\hline
\end{tabular}

Variabel dependen pada penelitian ini adalah pengambilan keputusan investasi mesin produksi, dan diukur menggunakan skala likert 1-10 dengan menunjukkan preferensi keyakinan subyek penelitian untuk melakukan atau tidak melakukan pengambilan keputusan investasi mesin produksi. Variabel independen pada penelitian ini adalah mental accounting dan self efficacy. Variabel mental accounting dalam penelitian ini diukur dengan menggunakan variabel dummy, di mana peneliti memberikan angka 1 untuk kondisi terdapat mental accounting dan angka 2 untuk kondisi tidak terdapat mental accounting. Variabel self efficacy dalam penelitian ini diukur dengan menggunakan variabel dummy, peneliti memberikan angka 2 untuk kondisi self efficacy yang rendah dan angka 1 untuk kondisi self efficacy yang tinggi.

Subyek penelitian ini adalah mahasiswa yang sedang menempuh pendidikan S1 Akuntansi Fakultas Ekonomi dan Bisnis Universitas Airlangga. Alasan peneliti memilih mahasiswa sebagai subyek penelitian adalah aspek yang diteliti berhubungan dengan aspek keprilakuan atau psikologisnya, yang diasumsikan tidak berbeda dengan para praktisi dalam suatu perusahaan, sehingga dianggap mampu sebagai subyek penelitian dalam tugas pengambilan keputusan investasi mesin produksi.

Pengujian hipotesis yang diajukan dalam penelitian ini dianalisis menggunakan Analyisis of Variance (ANOVA). Ghozali (2006) menjelaskan bahwa analisis of variance merupakan metode untuk menguji suatu hubungan antara satu variabel dependen dengan satu atau lebih variabel independen. ANOVA digunakan untuk mengetahui pengaruh utama (main effect) dan pengaruh interaksi (interaction effect) dari variabel independen terhadap variabel dependen. Pengaruh utama adalah pengaruh langsung variabel independen terhadap variabel dependen, sedangkan pengaruh interaksi adalah pengaruh bersama antara dua atau lebih variabel independen terhadap variabel dependen. 


\section{HASIL DAN PEMBAHASAN}

Penelitian ini dilakukan pada mahasiswa S1 Akuntansi Fakultas Ekonomi dan Bisnis Universitas Airlangga yang dilaksanakan pada tanggal 31 Mei 2017 dan 02 Juni 2017. Pada pelaksanaannya penelitian eksperimen ini melibatkan 109 sukjek penelitian, di mana $25(22,9 \%)$ data di antaranya tidak dapat diproses atau dianalisis lebih lanjut dengan alasan terdapat beberapa subjek penelitian yang tidak memberikan jawaban serta beberapa yang tidak lolos cek manipulasi. Sehingga jumlah subjek penelitian yang dapat dianalisis lebih lanjut sebanyak $84(77,1 \%)$, data penelitian sebagaimana dirangkum pada table 2 berikut ini.

Berdasarkan 84 subjek penelitian Table 2, data yang dapat dianalisis sebanyak 84 dengan nilai masing-masing respon keputusan investasi yang berbeda. Nilai respon tersebut menggunakan range antara 1-10 dengan tingkat keyakinan investasi oleh subjek penelitian.

Tabel 2. Hasil Penelitian

\begin{tabular}{lccccc}
\hline \multicolumn{1}{c}{ Subjek Penelitian } & Grup 1 & Grup 2 & Grup 3 & Grup 4 & Jumlah \\
\hline Mahasiswa S1 Akuntansi & 29 & 26 & 27 & 27 & 109 \\
Data yang tidak dapat dianalisis & 8 & 5 & 6 & 6 & 25 \\
Data yang dapat dianalisis & 21 & 21 & 21 & 21 & 84 \\
\hline
\end{tabular}

Matriks eskperimen bertujuan untuk menunjukkan hasil penelitian pada masingmasing sel. Pada Tabel 3 menunjukkan bahwa pada grup 1, di mana 21 subjek penelitian memilih untuk melakukan investasi mesin produksi dengan nilai rata-rata 8,62 dan standar deviasi 0,8. Pada grup 2, 14 subjek penelitian memilih untuk melakukan investasi mesin produksi dan 7 subjek penelitian memilih untuk tidak melakukan investasi mesin produksi. Keduanya memiliki nilai rata-rata 6,14dan standar deviasi 2,06. Sementara untuk nilai rata-rata kombinasi antara grup 1 dan 2 sebesar 7,4 dan standar deviasi 1,99 .

Grup 3 juga ditunjukkan dalam Tabel 3, yaitu 12 subjek penelitian memilih untuk melakukan investasi mesin produksi dan 9 subjek penelitian memilih untuk tidak melakukan investasi mesin produksi dengan nilai rata-rata 5,8 dan standar deviasi 2,41. Pada grup 4, 4 subjek penelitian memilih untuk melakukan investasi mesin produksi dan 17 subjek penelitian memilih untuk tidak melakukan investasi mesin produksi dengan nilai rata-rata 4,52 dan standar deviasi 1,89. Sementara untuk nilai rata-rata kombinasi antara grup 3 dan 4 sebesar 5,14 dan standar deviasi 2,22.

Pada kombinasi antara grup 1 dan 3 menghasilkan nilai rata-rata 7,2 dan standar deviasi 2,29. Sedangkan pada kombinasi antara grup 2 dan 4 menghasilkan nilai rata-rata 5,33 dan standar deviasi 2,11. 
Tabel 3. Matriks Eksperimen

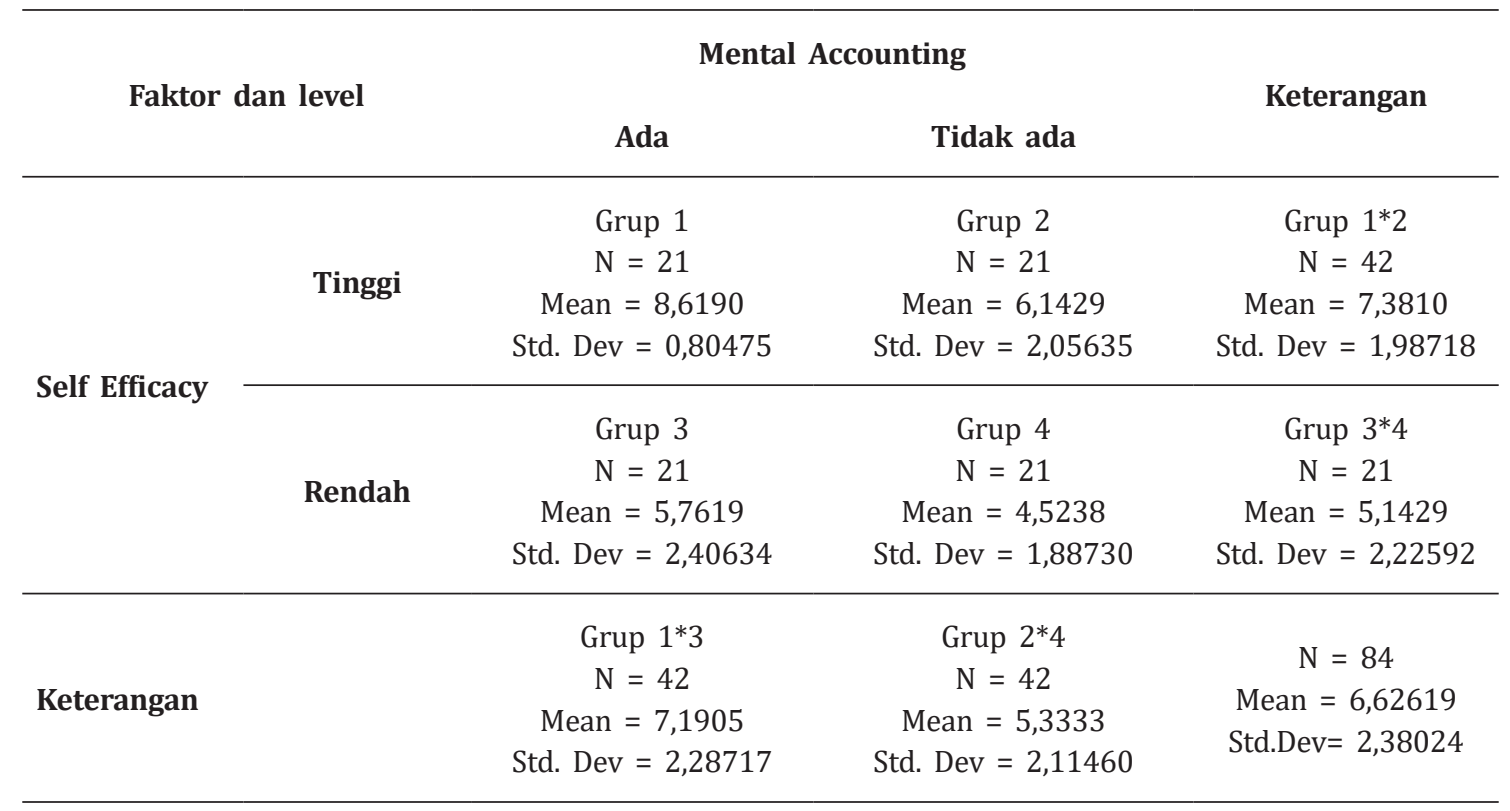

Pengujian hipotesis dilakukan melalui beberapa tahapan, untuk hipotesis 1 dan 2 dilakukan dengan menggunakan One Way Anova, hal ini dilakukan untuk menguji main effect dari variabel mental accounting dan self efficacy terhadap pengambilan keputusan investasi mesin produksi secara sendiri-sendiri. Pada hipotesis 3 menggunakan Two Way Anova karena bertujuan untuk mengetahui interaction effect dari variabel mental accounting dan self efficacy terhadap pengambilan keputusan investasi secara bersama-sama. Hasil pengujian hipotesis 1 , 2, dan 3 disajikan dalam tabel 4 di bawah ini.

Tabel 4. Hasil Uji Hipotesis

\begin{tabular}{cccc}
\hline Variabel Independen $(\mathbf{X})$ & F & Signifikan & Keterangan \\
\hline Mental accounting & 20,361 & 0,000 & $\mathrm{H}_{1}$ tidak ditolak \\
Self Efficacy & 29,572 & 0,000 & $\mathrm{H}_{2}$ tidak ditolak \\
Mental Acc*Self Eff & 2,262 & 0,136 & $\mathrm{H}_{3}$ ditolak \\
\hline
\end{tabular}

Berdasarkan Tabel 4, pengujian $\mathrm{H}_{1}$ dengan uji signifikansi, untuk $\mathrm{H}_{1}$ nilai signifikansi sebesar 0,000. Hasil ini memperlihatkan bahwa variabel $\mathrm{X}_{1}$ atau Mental accounting berpengaruh secara signifikan terhadap keputusan investasi mesin produksi. Pengujian $\mathrm{H}_{2}$ dengan uji signifikansi, untuk $\mathrm{H}_{2}$ nilai signifikansi sebesar 0,000. Hasil ini memperlihatkan bahwa variabel $\mathrm{X}_{2}$ atau Self efficacy berpengaruh secara signifikan terhadap keputusan investasi mesin produksi. Pengujian untuk $\mathrm{H}_{3}$ nilai signifikansi sebesar 0,136. Hasil ini memperlihatkan bahwa variabel $\mathrm{X}_{3}$ atau Mental accounting dan Self efficacy bersama-sama tidak berpengaruh secara signifikan terhadap keputusan investasi mesin produksi. 
Berdasarkan hasil pengujian, diperoleh nilai signifikansi sebesar 0,000. Hal ini menunjukkan bahwa manajer dalam kondisi mental accounting cenderung akan melakukan investasi mesin produksi. Kondisi mental accounting yang dialami oleh manajer ini mengharuskan memilih kredit pembiayaan mesin produksi daripada membelinya secara tunai. Kondisi tersebut juga membuat manajer meenganggap bahwa alternative terbaik adalah dengan membeli mesin produksi secara kredit, meskipun mengabaikan tingkat suku bunga yang lebih tinggi. Alternatif tersebut juga mendukung rencana awal bahwa deposito yang dimiliki perusahaan akan digunakan sesuai rencana awal. Hasil penelitian ini menyatakan bahwa dalam kondisi mental accounting, manajer mengabaikan perbandingan tingkat suku bungan antara tabungan deposito yang dimiliki dengan bunga kredit. Sehingga demi kedua rencana awal perusahaan dan investasi mesin produksi tercapai, manajer memilih untuk investasi mesin produksi melalui pembiayaan kredit.

Hasil penelitian ini menunjukkan bahwa mental accounting merupakan salah satu representasi dari dua faktor yang mempengaruhi pengambilan keputusan investasi, yaitu behavior finance. Dengan demikian hasil penelitian ini mendukung apa yang dikatakan Nagy \& Obenberger (1994) bahwa faktor-faktor yang mempengaruhi pengambilan keputusan investasi menjadi dua hal, yaitu faktor ekonomi dan faktor behavior finance. Salah satu representasi dari behavior finance adalah mental accounting. Hasil ini juga mendukung pernyataan dari Thaler (1985), Seiler dkk (2012), dan Rengku (2012) bahwa mental accounting menjadi pertimbangan tersendiri dalam pengambilan keputusan investasi.

Di sisi lain hasil penelitian ini tidak mendukung hasil penelitian yang dilakukan oleh Dewanti dkk (2018), dimana pertimbangan utama investor ialah return dan bukan mental accounting. Sementara hasil penelitian ini juga tidak mendukung penelitian Duxbury dkk. (2005) yang menetapkan penerapan umum mental accounting dengan investigasi beragam keputusan dalam kondisi yang bervariasi, sehingga pengaruh mental accounting tidak ada pada pengambilan keputusan individu.

Hipotesis $2\left(\mathrm{H}_{2}\right)$ yang diajukan dalam penelitian ini adalah manajer dalam kondisi self efficacy tinggi akan cenderung melakukan investasi mesin produksi. Berdasarkan hasil pengujian, diperoleh nilai signifikansi sebesar 0,000. Hal ini menunjukkan bahwa manajer dalam kondisi self efficacy tinggi cenderung akan melakukan investasi mesin produksi. Salah satu representasi dari behavior finance adalah self efficacy. Hasil penelitian ini mendukung pernyataan dari Bandura (1978), Eveline (2010), Reed dkk (2012), dan Farrell dkk (2016) bahwa self efficacy berpengaruh terhadap keputusan investasi. Penelitian eksperimen ini juga sesuai dengan temuan Whyte dkk (1997) mengenai self efficacy bahwa pada kondisi self efficacy yang tinggi, subyek cenderung akan melakukan investasi. Sedangkan sebaliknya, pada kondisi self efficacy yang rendah subyek cenderung tidak melakukan investasi. Hasil penelitian ini juga mendukung pernyataan yang sama ditemukan oleh Montford and Goldsmith (2016), bahwa keyakinan diri yang tinggi berpengaruh terhadap pemilihan investasi yang berisiko. 
Hipotesis $3\left(\mathrm{H}_{3}\right)$ yang diajukan dalam penelitian ini adalah manajer dalam kondisi ada mental accounting dan self efficacy yang tinggi akan cenderung melakukan investasi mesin produksi. Dengan demikian, Hipotesis nol $\left(\mathrm{H}_{0}\right)$ adalah manajer dalam kondisi ada mental accounting dan self efficacy yang rendah cenderung tidak melakukan investasi mesin produksi. Berdasarkan hasil pengujian, diperoleh nilai signifikansi sebesar 0,136. Nilai tersebut lebih besar daripada taraf signifikansi $5 \%$ atau $(0,136>0,05)$ sehingga dapat disimpulkan bahwa hipotesis $3\left(\mathrm{H}_{3}\right)$ ditolak dan hipotesis nol $\left(\mathrm{H}_{0}\right)$ tidak ditolak. Hal ini menunjukkan bahwa manajer dalam kondisi ada mental accounting dan self efficacy yang tinggi cenderung tidak melakukan investasi mesin produksi.

Hasil penelitian ini juga menunjukkan bahwa tidak terjadi interaksi secara bersamasama antara variabel mental accounting dan self efficacy terhadap pengambilan keputusan investasi mesin produksi. Gambar 1 menyajikan hasil interaksi antara mental accounting dan self efficacy.

Gambar 1. Hasil Interaksi Mental accounting dan Self efficacy

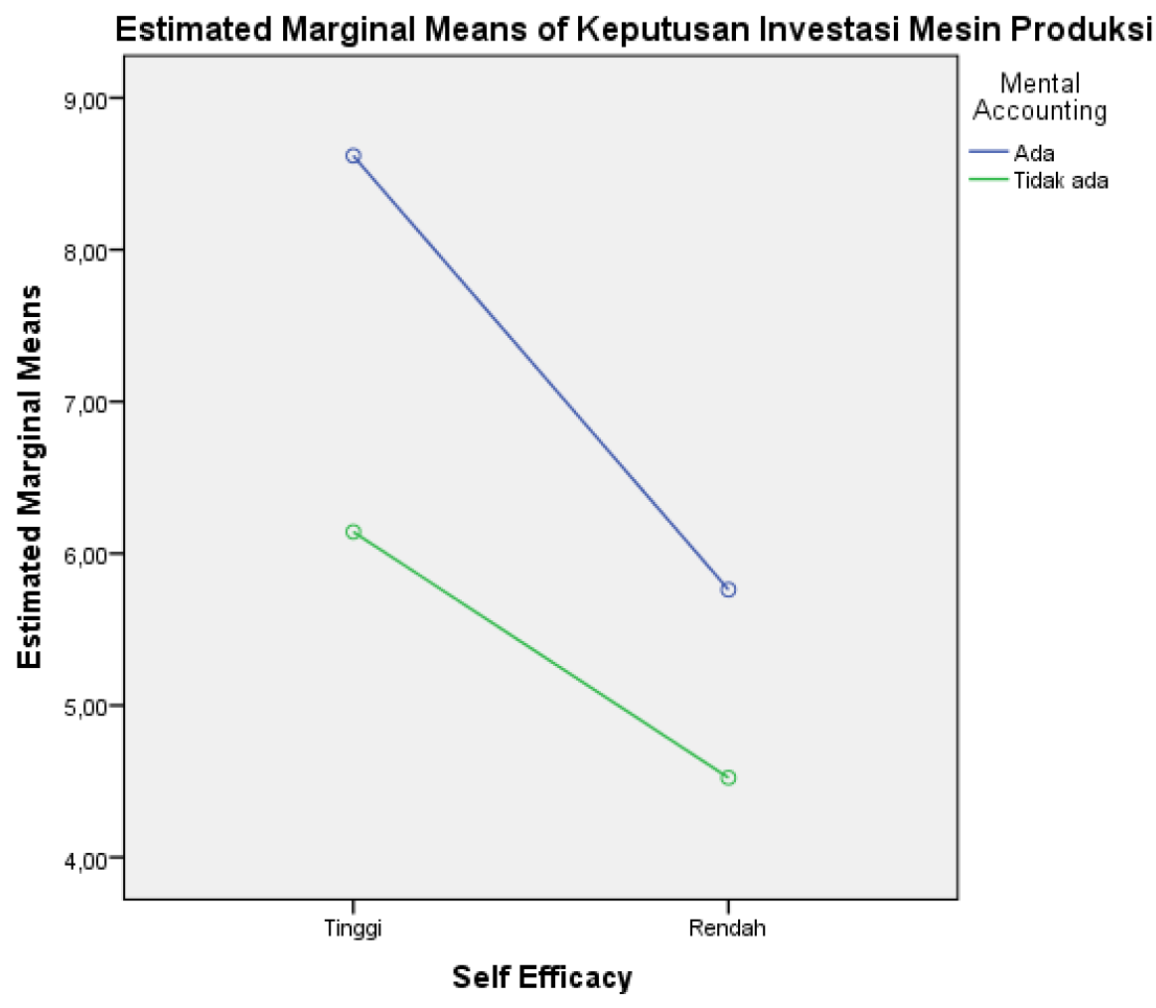

Gambar 1 menunjukkan bahwa manajer dalam kondisi ada mental accounting cenderung meningkatkan preferensi untuk melakukan investasi mesin produksi ketika mendapat perlakuan dalam kondisi self efficacy yang tinggi. Manajer dalam kondisi ada mental accounting cenderung stabil preferensinya untuk melakukan investasi mesin produksi ketika mendapat perlakuan dalam kondisi self efficacy yang rendah. Selanjutnya, manajer dalam kondisi ada mental accounting cenderung stabil preferensinya untuk melakukan investasi mesin produksi ketika mendapat perlakukan dalam kondisi self efficacy yang rendah. 
Sebaliknya, manajer dalam kondisi tidak ada mental accounting cenderung menurunkan preferensi untuk melakukan investasi mesin produksi ketika mendapat perlakuan self efficacy yang rendah.

Hal ini dikarenakan manajer lebih melihat tingkat self efficacy mereka daripada terdapat atau tidaknya mental accounting. Hasil tersebut juga menunjukkan bahwa variabel mental accounting tidak memperkuat self efficacy dalam pengambilan keputusan investasi. Dengan demikian, secara interaksi variabel mental accounting dan self efficacy tidak berpengaruh terhadap pengambilan keputusan investasi.

\section{SIMPULAN}

Berdasarkan hasil penelitian dan pembahasan mengenai mental accounting dan self efficacy terhadap pengambilan keputusan investasi mesin produksi maka dapat ditarik kesimpulan bahwa mental accounting berpengaruh terhadap pengambilan keputusan investasi. Di mana manajer dalam kondisi ada mental accounting cenderung akan melakukan investasi mesin produksi. self efficacy juga berpengaruh terhadap pengambilan keputusan investasi. Di mana manajer dalam kondisi self efficacy yang tinggi cenderung akan melakukan investasi mesin produksi. Sementara mental accounting dan self efficacy secara interaksi tidak berpengaruh terhadap pengambilan keputusan investasi. Sehingga dapat disimpulkan bahwa mental accounting tidak terbukti dapat memperkuat hubungan antara self efficacy dengan pengambilan keputusan investasi mesin produksi.

Hasil penelitian menunjukkan terdapat satu hipotesis yang tidak terbukti, disebabkan subjek penelitian lebih melihat pada self efficacy yang digunakan daripada ada atau tidaknya mental accounting. Peneliti eksperimen selanjutnya diharapkan agar dapat mengemas kondisi mental accounting dengan baik dan berdasarkan tiga kasus populer mengenai mental accounting. Peneliti selanjutnya diharapkan dapat membuat kolaborasi variabel mental accounting dengan variabel lain, misalnya dengan variable gender. Hal ini agar dapat mengetahui peran mental accounting dalam memperkuat atau tidaknya terhadap pengambilan keputusan investasi mesin produksi.

\section{PUSTAKA ACUAN}

Bakar, S., \& Yi, A. N. C. (2016). The Impact of Psychological Factors on Investors' Decision Making in Malaysian Stock Market: a Case of Klang Valley and Pahang. Procedia Economics and Finance, 35, 319-328. https://doi.org/10.1016/S22125671(16)00040-X.

Bandura, A. (1978). Self-Efficacy: Toward a Unifying Theory of Behavioral Change. Advances in Behaviour Research and Therapy, 1(4), 139-161.

Biyanto, F. (2001). Hubungan Pembingkaian Informasi Anggaran, Tanggung Jawab, Dan Pengalaman Terhadap Pilihan Keputusan Pada Investasi Berisiko. Disertasi Tidak Dipublikasikan. Yogyakarta: Universitas Gadjah Mada. 
Dewanti, P. W., Priantinah, D., \& Kurniasari, W. A. (2018). Mental Accounting dalam Keputusan Investasi. Jurnal Akuntansi, 6(1), 75-87. https://doi.org/10. 24964/ ja.v6i1.687.

Duxbury, D., Keasey, K., Zhang, H., \& Chow. S. L. (2005). Mental Accounting and Decision Making: Evidence under Reverse Conditions Where Money Is Spent for Time Saved. Journal of Economic Psychology, 26(4) 567-580.

Eveline, F. (2010). Pengaruh Adverse Selection, Pembingkaian Negatif, Dan Self Efficacy Terhadap Eskalasi Komitmen Proyek Investasi Yang Tidak Menguntungkan. Jurnal Akuntansi dan Manajemen, 21(2), 181-198.

Farrell, L., Fry, T. R. L., \& Risse, L. (2016). The Signifcance of Financial Self-Efficacy in Explaining Women's Personal Finance Behaviour. Journal of Economic Psychology, 54, 85-99. https://doi.org/10.1016/j.joep.2015.07.001.

Ghozali, I. (2006). Aplikasi Analisis Multivariate Dengan Program SPSS. Semarang: Badan Penerbit Universitas Diponegoro.

Kahneman, D., \& Tversky, A. (1979). Prospect Theory: An Analysis of Decision under Risk. Econometrica, 47(2), 363-391.

Kahneman, D., \& Tversky, A. (1984). Choices, Values, and Frames. American Psychologist, 39, 341-350.

Montford, W., \& Goldsmith, R. E. (2016). How Gender and Financial Self-Efficacy Influence Investment Risk Taking. International Journal of Consumer Studies, 40(1), 101-106.

Nagy, R. A., \& Obenberger, R. W. (1994). Factors Influencing Individual Investor Behavior. Financial Analysts Journal, 50(4), 63-68. https://doi.org/10.2469/faj.v50.n4.63

Nahartyo, E., \& Utami, I. (2016). Panduan Praktis Riset Eksperimen. Jakarta: Indeks.

Porter, M. E. (1989). How Competitive Forces Shape Strategy. In Asch, D., \& Bowman, C. (eds). Readings in Strategic Management. London: Palgrave.

Reed, A. E., Mikels, J. A., \& Löckenhoff, C. E. (2012). Choosing with Confidence: Self-Efficacy and Preferences for Choice. Judgement and Decision Making, 7(2), 173-180.

Rengku, R. B. (2012). Faktor Internal Dan Pengaruhnya Terhadap Risk Perception dan Expected Return Perception. Journal of Business \& Banking (JBB), 2(2),185-198.

Ritter, J. R. (2003). Behavioral Finance. Pacific-Basin Finance Journal, 11(4), 429-437. https://doi.org/10.1016/S0927-538X(03)00048-9.

Seiler, M. J., Siler, V. L., \& Lane, M. A. (2012). Mental Accounting and False Reference Points in Real Estate Investment Decision Making. Journal of Behavioral Finance, 13(1), $17-$ 26. https://doi.org/10.1080/15427560.2012. 653293.

Thaler, R. (1985). Mental Accounting and Consumer Choice. Marketing Science, 4(3), 199214. https://doi.org/10.1287/mksc.4.3.199.

Whyte, G., Saks, A. M., \& Hook, S. (1997). When Success Breeds Failure: The Role of Self Efficacy in Escalating Commitment to a Losing Course of Action. Journal of Organizational Behavior, 18(5), 415-432. 
Whyte, G., \& Saks, A. M. (2007). The Effects of Self-Efficacy on Behavior in Escalation Situations. Human Performance, 20(1), 23-42. https://doi.org/ 10.1080/ 08959280709336927. 